\title{
Recent trends in publications of economic historians in Europe and North America (1980-2019): an empirical analysis
}

\author{
Nadia Fernández-de-Pinedo ${ }^{1}$ - Alvaro La Parra-Perez ${ }^{2}$. \\ Félix-Fernando Muñoz ${ }^{1}$ (D)
}

Received: 29 October 2021 / Accepted: 25 January 2022 / Published online: 15 February 2022

(C) The Author(s) 2022, corrected publication 2022

\begin{abstract}
This article analyses the integration of economic history into economics using a unique dataset containing 11,143 articles written by 919 economic historians and published between 1980 and 2019 in leading journals; we also analyzed the authors' biographical information. Using a probit regression, we find that since 1980, economic historians have increased their likelihood of publishing in Economics or Finance Journals (EFJs) by 12 points. This integration is more marked in North America than in Europe because North American economic historians are more likely to be trained in the discipline of economics. In contrast, a significant share of scholars in Europe are trained in the discipline of economic history. Network visualizations confirm these regional differences: citations to EFJs are much more central in North American scholars' work. Our findings support Robert Margo's claim that economic history is currently integrated into economics more often in publications in North America than in Europe.
\end{abstract}

Keywords Scholarly identity · Economics and economic history $\cdot$ Citation analysis · Dataset · Bibliographic analysis · Europe and North America

JEL Classification A12 · N01

Félix-Fernando Muñoz

felix.munoz@uam.es

1 Deptartamento de Análisis Económico: Teoría Económica e Historia Económica, Universidad Autonoma de Madrid, Madrid, Spain

2 Department of Economics, John B. Goddard School of Business \& Economics, Weber State University, Ogden, UT, USA 


\section{Introduction}

This article uses the dataset EconHist to add to the growing literature on the integration of economic history into economics. EconHist contains information on 11,143 articles (co)authored by 919 economic historians between 1980 and 2019 . When looking at the probability of economic historians publishing in Economics or Finance Journals (EFJs), our results support Robert Margo's findings that economic history is integrated into economics (Margo 2018). Our findings suggest that this integration has regional differences: it currently occurs more often in North American than in European scholarship. One novel aspect of this article is the study of the factors behind these geographical trends by using authors' biographical and professional data. How do professional, academic, institutional, or other factors explain the differences in integration? Our results suggest that the difference comes mostly from the disappearance of economic history as a separate discipline or doctoral program in the USA. North American economic historians are trained in the discipline of economics and publish most of their work in EFJs. However, European scholars with a Ph.D. in economic history tend to publish evenly between EFJs and Economic/Business History Journals (EBHJs). Network visualizations confirm that the differences on both sides of the Atlantic go beyond the types of journals selected by these authors. For example, economic historians in North America cite EFJs more often than do economic history-trained scholars in Europe.

The questions in this article are related to several studies that have focused on the present and future of economic history as an autonomous discipline, the contribution of other disciplines (including economics, cliometrics, or history) to the field, and the use of quantitative methods in economic history (Margo 2018, 2021). Diebolt and Haupert (2021), for example, review the origins of economic history in Europe and the USA in the nineteenth century, the spread of economic history at the beginning of the twentieth century, the creation of economic history associations, the birth of cliometrics in the 1960s, and the current predictions of doom and criticism. In their words, 'To understand the current status and future prospects of economic history, it will be necessary to understand its past' (Ibid. 1).

Valuable research contributions have focused on:

- The impact of economic history on scientific production For example, Abramitzky (2015), Baten and Muschallik (2012), Cioni et al. (2020a, 2020b, 2021), Fernández-de-Pinedo and Muñoz (2019), Fourie (2019), and Jones et al. (2012) study the relationship between economic history and economics by analyzing the output of specific journals or by sampling leading EFJs and EBHJs. These authors' strategies are diverse. For example, Abramitzky (2015) reviews the role of economic history in economics by analyzing the percentage of economic history papers published in the top five EFJs. We note here that although some scholars have broad geographic approaches (see Baten and Muschallik 2012; Fourie and Gardner 2014; Fourie 2019; Mihaljevic 2019;), they have generally limited their analyses to European and North American journals. 
- The alienation among economists, cliometricians, and historians This poses particular consequences for the discipline of economic history. These concerns started with Romer's discussion of the 'accomplishments of this melding of economic history with the rest of economics' (Romer 1994, 50). Since then, a growing literature illustrates the influence of or merging of economics with other social sciences and empirical methodologies (Boldizzoni 2011; Greasley and Oxley 2010; Jones et al. 2012; Lamoreaux 2015; Lyons et al. 2007; Margo 2018; McCloskey 1976; Mitchener 2015; Reckendrees 2017; Romer 1994; Temin 2013; Waldenström 2005). Among the most prolific authors in this area are Diebolt, Haupert, and colleagues (Diebolt and Demeulemeester 2007; Diebolt and Haupert 2016, 2018, 2020, 2021; Haupert 2017). According to them, economic history scholars must view simultaneously the two directions that can be taken: Let economic history become a dead discipline or a growing discipline through economics (Diebolt and Haupert 2021).

- Bibliometric methods to explore citation patterns in samples of specific journals, networks of coauthorship, and sources These methods are used in much of the recent research of economic history articles in major EFJs (see Abramitzky 2015; Collins 2015; Di Vaio and Weisdorf 2010; Eloranta et al. 2010; Galofré-Vilà 2020; Hamermesh 2018; Ojala et al. 2017; Seltzer 2018; Seltzer and Hamermesh 2018; Stigler et al. 1995; Whaples 1991, 2002). For example, Collins analyses coauthorship in economic history and economics from 1963 to 2011, and specifically pinpoints that 'co-authorships in economic history are more likely to be formed of individuals of different seniority as compared to economics generally' (Seltzer and Hamermesh 2018). Diebolt and Haupert (2019) compare the percentage of citations of economics literature in EBHJ articles to the percentage of such citations in non-EBHJs.

- Trends in topics and publications that discuss the past and current frontier of the research agenda on the field The authors studying this trend include Angrist et al. (2017), Collins (2018), Cioni et al. (2021), Margo (2011, 2021), Mihaljevic (2019), Romer (1994); Seltzer (2018), and Wehrheim (2019). Wehrheim (2019) looks at topics in the Journal of Economic History and points out the growing use of econometric language. Cioni et al. (2021) survey the use of quantitative tools in the three top economic history journals, while Diebolt and Haupert (2021) emphasize the promising application of new datasets and analytical techniques for the economic history discipline.

- A focus on the practitioners of economic history and how their heterogeneous backgrounds might explain differences in research practices and motivation for publishing This focus is seen in Baten and Muschallik (2012), Cioni et al. (2018, 2021), Margo (2018), Mitch (2011), and Poelmans and Rousseau (2016). For example, according to Cioni et al. (2018: 4), economic historians 'working in Economics department aim at publishing their works as articles in international journals with impact factor. They regard journals without impact factor as the second best and books with major international publishing houses only as their third option'. Seltzer (2018: 21) states that 'the old path to promotion for an economic historian of publishing big books has been replaced by a new path of publishing in top-ranked journals'. However, Abramitzky 
(2015: 1248) points out that 'unlike the average economist, economic historians still read and write books'. Margo, meanwhile, tracks the publication histories of successive cohorts of "scholars in the first decade after receiving their doctorate (Margo 2021, 10). The academic labor market continues to be conditioned by new graduates who 'are evaluated for tenure and promotion by an older generation of scholars', limiting any new wave of revolution in the field (Margo 2021: 10).

Of course, every research strategy has its limitations. For example, Margo (2018) conducted a text analysis of articles published in five Economics journals where he finds that economic historians use more econometric language and have increasingly published more in economics over time. However, Margo's survey focuses on a limited number of North American scholars and a limited number of journals (two in economic history, two in labor economics, and the top 5 economic journals).

Cioni et al. (2020a, b, 2021) explore several trends in economic history but their analysis conflates articles published by economic historians and by 'historical economists' ${ }^{1}$. In particular, they focus on what they call the two revolutions in economic history: 'The affiliations of authors and the number of citations as a proxy for their scientific impact' (Cioni et al. 2021, 18). Contrary to Margo, they find that economic history's integration into economics has stopped over the last decades. However, the metric Cioni et al. use is the percentage of economic history articles in top economics journals (Cioni et al 2021, 18) ${ }^{2}$. This metric may be problematic because it excludes some journals. Also, Margo (2021) finds that there has been a decline in North American graduates in Economics departments who specialize in economic history. If the number of economic historians is decreasing-at least in North America-a constant or even decreasing share of articles in economic history in EFJs do not necessarily imply that economic historians are publishing less often in them.

The criteria used to define economic history, its practitioners, and their work, of course, significantly affect the sample size and the results. Who is an economic historian $?^{3}$ Is it someone who uses data from centuries ago? Or even just

\footnotetext{
1 According to Bisin and Federico (2021a, b: xv): 'Cliometricians studied the economic past for the sake of its knowledge, while most recently historical economists often search in the past the answer to questions about current economic conditions. (...) At the same time, modern work in historical economics is also characterized by resorting to state-of-the-art econometrics to identify causal relationships and by a more explicit relationship between empirical analysis and theoretical models. The essence of the new wave is well represented by the work of Daron Acemoglu, James Robinson, and co-authors on the role of institutions in economic growth'.

2 They create two databases that 'include a total of 2,888 articles on economic history issues, published from 2001 to 2019 in the top five economic history journals (2286) and in the thirteen economic journals selected (602)-in the top five economics journals (220), in the other three major generalist economics journals (186), in the two "history friendly" journals (118), and in the three top field ones (78)'. See also Cioni et al (2021: 26).

3 Although economic history is a well-defined discipline, 'surprisingly little is known about the scholars who represent economic history' (Baten and Muschallik, 2012: 95) and what economic historians do (Whaples 1991).
} 
decades ago? Or is it someone who publishes in EBHJs, or who lists economic history as their main field of interest? Perhaps, it is a combination of these criteria. Moreover, which work from economic historians should be considered? Should it be all of their publications, or only those in top-ranked general or specialized field journals? Different studies have taken different approaches to answering these questions. Our dataset takes a revealed-preference approach to identify the sample of economic historians. Anyone who is linked (via membership or participation at conferences) to one or more of the four leading economic history associations (Economic History Association, Economic History Society, Cliometrics Society, or European Historical Economics Society) is included in the dataset. We use an inclusive approach regarding their publishing output by considering all their peer-reviewed articles published since 1980 and indexed in Scopus (i.e., 11,143 articles).

Of course, our strategy cannot wholly escape the criticism launched at earlier similar research. ${ }^{4}$ For example, identifying economic historians through memberships or other links to economic history organizations excludes many practitioners who, for different reasons, have never joined them or participated in the selected conferences. In addition, our database focuses only on journal articles, which excludes books, book chapters, and other outputs such as reviews. The four economic history associations used to form our sample of practitioners in the field are based in North America or Europe, which explains why the majority of the sampled individuals studied currently work on those continents. However, our dataset is arguably more complete and varied than previous research because we relaxed some of the requirements or constraints about practitioners in economic history or their publication output. This allows for a more nuanced and representative view of the state of the discipline.

The rest of the article is organized as follows. Section 2 introduces EconHist, the dataset that provides our empirical material for analyzing the main traits and the production of our sample of economic historians. Sections 3 and 4 develop empirical analyses of the temporal, geographical, educational, professional, and other factors that correlate with the type of journals in which economic historians have published between 1980 and 2019. Section 5 delves further into the differences between economic history in North America and Europe by visualizing the networks of journals and authors cited by scholars on both sides of the Atlantic. Section 6 concludes.

\footnotetext{
${ }^{4}$ Biases are inevitable because as in precedent works included in our database (919) the selection also relies on the preponderance of North American and European scholars. Considering that, according to Baten's survey, there are about 10,700 economic historians in the world, we are analyzing a mere $8.6 \%$ of the population. Second, rather than focusing on publications in top field or general-interest journals, our analysis uses all the articles published between 1980 and 2019 by those individuals in different journals indexed in Scopus.
} 


\section{EconHist dataset and descriptive statistics}

The EconHist dataset contains information for 11,143 articles indexed in Scopus since 1980 and authored by 919 scholars of economic history ${ }^{5}$. The criteria for identifying economic historians were being a member of the Economic History Association or the Cliometric Society, and/or participating at the 2018 or 2019 annual meetings of the Economic History Society or the 2017 annual meeting of the European Historical Economics Society. ${ }^{6}$ The dataset provides individual information for the articles (such as title, journal name, publication year, and references used) and the authors (e.g., name, gender, work place, job position in 2019, university attended and year when $\mathrm{PhD}$ was awarded, and discipline of the degree). ${ }^{7}$ Although the associations and meetings that we use to identify economic historians have a clear Western bias, the dataset is useful for the comparison of scholars in Europe and North America.

We used the nearly 25,000 All Science Journal Classification Codes (ASJCs) provided by Scopus to identify journals that belong to the following three categories: Economics or Finance Journals (EFJs), Economic/Business History Journals (EBHJs), and History Journals (HJs) ${ }^{8}$. A journal was considered an EFJ if its codes related to economics (ASJCs 2000-2002) or finance (ASJC 2003), and an HJ if its ASJCs related to history (i.e., ASCJ 2012 or 1207). We imposed two conditions for a journal to be considered an EBHJ. First, all of its ASJCs must fall into either economics, finance, business, or history. Second, the journal must have at least one ASJC belonging to the economics, finance, or business group and one belonging to history. ${ }^{9}$

\footnotetext{
${ }^{5}$ Our database contains 75 of the 87 (86.2\%) US economic historians studied by Margo (2018). Some scholars are missing because they had passed away before we collected our data (e.g., Fred Bateman, Robert Fogel, Douglass North).

${ }^{6}$ Apart from the lists of members of economic history associations (which have no open access) or the names of academics who published in economic history journals, the censuses that collect those who self-identify as economic historians are scarce. In 2008 Helen Julia Paul, funded by the Economic History Society, created a census of economic historians in UK higher education. Baten and Muschallin (2012) sent an e-mail questionnaire across the world to build on the list of participants of the world economic history congresses and on the research leaders of the major economic history societies. It was answered by 242 to scholars.

${ }^{7}$ La Parra-Pérez et al. (2022) offers a detailed description of the EconHist dataset.

${ }^{8}$ The most updated list of journals can be found at https://www.scopus.com/home.uri. Click on "Scopus Source List." We used the 2018 version, which is available upon request. The complete list of ASJCs is available at https://service.elsevier.com/app/answers/detail/a_id/15181/supporthub/scopus/ (all links accessed on February 8, 2021).

${ }^{9}$ Online Appendix A provides a complete list of the titles that meet the criteria for each of the three groups. Some scholars consider business history to be a separate discipline from economic/business history (Ojala et al., 2017). Of the 2,899 articles in the dataset that fall into the EHBJ category, only 307 $(10.59 \%)$ were published in business history journals.
} 
Figure 1 shows the share of articles that were published in each type of journal by decade. ${ }^{10}$ North American authors show a more significant increase in EFJ publications over European scholars. For example, in the 1980s, approximately one in six articles published by North American economic historians were in EFJs. In the 2010s, it was approximately one in three. This is the opposite trend for EBHJs, in which the rate of publication for North American authors fell from 41 percent in the 1980 s to 21 percent in the 2010s. In contrast, EBHJs remain the primary publication choice for economic historians in Europe. Publications at HJs have always represented a minority in both regions, at around 5 percent (or less), and there has been a sustained decline in North America during the entire period considered in this article. ${ }^{11}$

Figure 1 shows an increasing trend for economic historians to publish in EFJs, which is consistent with the idea that economic history started to become more integrated into economics after the cliometric revolution in the 1960s. ${ }^{12}$ This trend could be the result of structural or compositional changes that have taken place in academia over the last few decades. The following section discusses an empirical strategy to study which factors correlate, ceteris paribus, with the probability of publishing in each type of journal.

\section{Empirical strategy}

The factors explaining author $i$ 's probability of publishing paper $p$ in each type of journal (EFJ, EBHJ, or HJ) can be divided into four broad groups: (1) characteristics of the paper $(P),(2)$ the scholar's training $(T),(3)$ professional incentives related to the characteristics and location of the scholar's job $(J)$, and (4) other individual characteristics $(R)$. In a general function specification:

$$
\text { Publishing at } X_{i, p}=f(P, T, J, R)
$$

where $X=\{E F J, E B H J, H J\}$ and the left-hand side of Eq. (1) is dichotomous because the publication either belongs to a journal from discipline $\mathrm{X}$ or it does not. We use a probit regression in the next section after defining our $P, T, J$, and $R$ variables.

\footnotetext{
${ }^{10}$ Assume there are $N$ authors in a given region with at least one publication in a given decade. Let $x_{a}$ denote the total number of articles that author $a$ published in that decade and $c_{a}$ the number of articles that $a$ published in a given type of journal (EFJ, EBHJ, or HJ). Figure 1 computes the following for each category of journal in a given decade for a given region: $\sum_{a=1}^{N} c_{a} / \sum_{a=1}^{N} x_{a}$.

${ }^{11}$ If, instead of using a share of total articles in a given type of journal by decade, we compute the average share of articles by author published in that type of journals during the decade (i.e., $\left(\sum_{a=1}^{N} \frac{c_{a}}{x_{a}}\right) / N$; see note 10 for notation), then the share of publications in EFJs in North America is equal (but not greater) to the share for publications in EBHJs. This suggests that the more prolific authors in North America publish more often in EFJs.

${ }^{12}$ Percentages do not add to 100 because the figure excludes publications in journals that are not classified as EFJ, EHBJ, or HJ. For example, a journal with three ASJCs (one in economics, another in history, and another in political science) would not belong to EFJ (because two ASJCs are outside economics or finance), nor to EBHJ (there is a political science ASJC), nor to HJ (due to the two ASJCs outside history).
} 


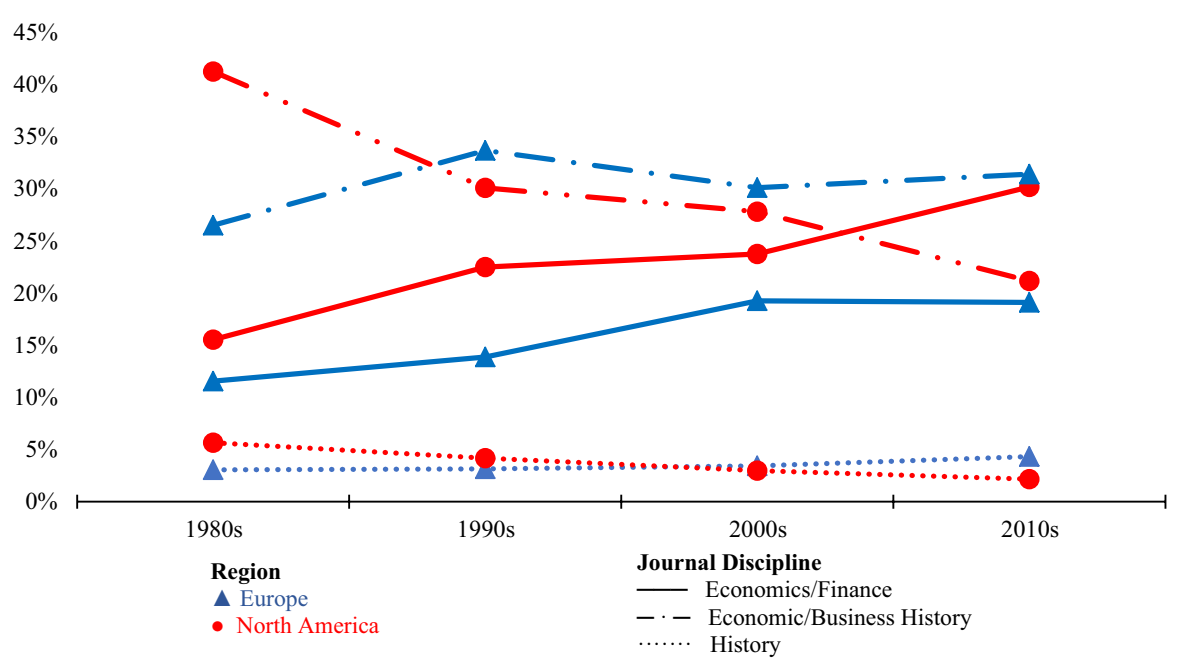

Fig. 1 Percentage of articles published by economic historians in EFJs, EBHJs, and HJs, by decade and region

To assess the integration of economic history into economics, our primary variable of interest is a control for the year when article $p$ was published $\left(\right.$ Year $\left._{p}\right)$. If economic history is becoming more integrated into economics, a higher $Y e a r_{p}$ should be significantly and positively correlated with a higher likelihood of publishing in an EFJ.

We also use authors' biographical information, along with some article characteristics, to control for factors that might influence the likelihood of publishing in a certain type of journal. For example, we include the number of coauthors who penned

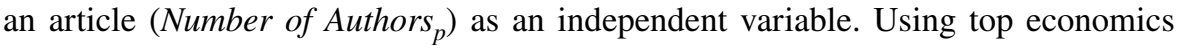
and economic history journals, Seltzer and Hamermesh (2018) find that coauthorship in economic history is still more uncommon than in economics, even though there has been a roughly parallel increase in collaborative work in both disciplines during the last few decades. In top HJs, authorship is still mostly an individual activity. Authors attribute the difference in levels of coauthorship to the different norms across disciplines, especially in Europe. They also hypothesize that the upward trend of coauthorship in both economics and economic history corresponds to the similar professional incentives faced by economists and economic historians located in Eco-

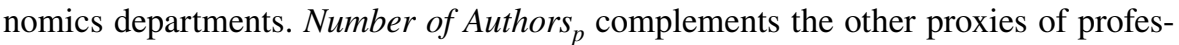
sional incentives ( $J$ in Eq. 1), as detailed below.

The probability of publishing in each type of journal is also conceivably influenced by a scholar's education and training ( $T$ in Eq. 1 ), which is why we include dummy variables for an individual's type of Ph.D. (Economics or Finance, 
Economic History, or History). We also control for the year when author $i$ was awarded their degree $\left(\right.$ YearPhD $\left.D_{i}\right)$ to account for potential differences across cohorts of graduates. 13

Finally, for other aspects of $J$ in Eq. 1, we include a series of indicators for scholars who taught in Business/Accounting/Management, Economics or Finance, Economic History, or History departments in 2019 (Department ${ }_{2019 i}$ ). Because we observe the type of department only in year 2019, the relationship with publications in that field is probably endogenous. On the one hand, the professional incentives for people working in departments from a given discipline guide their submission decisions to journals from that discipline (Poelmans and Rousseau 2016). On the other hand, individuals more interested in discipline $\mathrm{X}$ are more likely to publish in $\mathrm{X}$ journals, leading to their hiring in $\mathrm{X}$ department. Our empirical strategy cannot disentangle the reverse causality between an individual's department and their types of publications.

From a geographical point of view, it has been noted that both the cliometric revolution and some of the recent changes in economic history that has furthered the integration into economics are mostly North American movements (Cioni et al. 2021: 28). To account for potential differences in the practice of the discipline across regions, we include dummy variables for the continent on which the individual was working in $2019\left(\right.$ Region $\left._{i}\right) .{ }^{14},{ }^{15}$

We also include indicators for other individual characteristics ( $R$ in Eq. 1), such as gender $\left(\right.$ Male $\left._{i}\right)$ and membership or attendance to the conferences of the four economic history associations used to build our dataset $\left(\right.$ Affiliation $\left._{i}\right)$. Finally, we include an indicator that identifies those authors with the highest number of publications $\left(\right.$ TopAuthor $_{i}$ ). This variable equals 1 if the individual is in the top decile for the total number of articles published or the average number of articles published each year for those awarded their degree in 2014 or earlier. TopAuthor ${ }_{i}$ also serves as a proxy for authors who work in more research-oriented organizations or units. ${ }^{16}$

\footnotetext{
13 See La Parra-Pérez et al. (2022) for more details on how these indicators are built. If an individual was awarded more than one doctorate, the year reflects the oldest degree.

14 We do not include regional dummies for region where the degree was awarded because they are highly correlated with the region of work. The Spearman correlation index between region of work and region of study for scholars working in North America and Europe in 2019 is, respectively, 0.7677 and 0.7883

15 The main challenge when controlling for Region comes from individuals who switched continents during their careers (about 8 percent of individuals in the database). Imagine someone who spent the years 2000 to 2005 in North America but started working in Europe in 2006. If this individual was published in 2006, it is almost certain that the work was developed in North America, even if it was published after this person moved to Europe. This is why we assume a three-year lag between the genesis of a project and its final publication. In this example, all publications between 2003 and 2008 were considered to be written by a North American-based author. Needless to say, the time between the genesis of a project and its publication is extremely idiosyncratic because decision times vary considerably among disciplines, and even across journals within a discipline. Ellison (2002) finds that time between submission and acceptance at top EFJs increased from about six months in the 1960s to 1.5-2 years in the late 2000s. Thus, assuming three years between the start of a project and its publication seems reasonable.

${ }^{16}$ When computing the top decile for average publications per year, we excluded individuals who were awarded their degree after 2014 to avoid the potentially artificial bump in the metric resulting from the publication of the chapters that typically form the foundation of Ph.D. dissertations in economics.
} 
Table 1 presents the summary statistics. More than one-fourth (28 percent) of the articles published by the authors in our dataset appeared in EBHJs and 22 percent in EFJs. ${ }^{17}$ History journals represent only 3 percent of authors' publications. The authors are disproportionally male ( 85 percent), ${ }^{18}$ members of the Economic History Association and/or the Cliometric Society (61 and 55 percent, respectively), tend to hold a Ph.D. in economics (71 percent), and tend to work in Economics departments (71 percent). Most authors in the sample holding a doctorate in economic history or working in an Economic History department studied and are currently working in Europe (89 percent and 93 percent, respectively). ${ }^{19}$ Only 122 individuals (13.28 percent) in our sample meet our criteria for 'top author'; they account for a large share of articles, at 43.5 percent, and are part of what we are calling the "bibliometric elite." As noted above, our sample has a clear Western bias (92 percent of authors are located in Europe or North America), which naturally follows from the associations used to identify economic historians and their work.

\section{Main results}

We estimate the coefficients for the following probit regression model for the type of journal where author $i$ published article $p$ :

$$
\begin{aligned}
& \text { Model } 1 \\
& \operatorname{Pr}\left(\text { Category Journal }_{i p}\right)= \\
& \Phi\left(\begin{array}{l}
\alpha+\beta_{1} \cdot \text { Year }+\beta_{2} \cdot{\text { Number Of Authors }+\beta_{3} \cdot \text { Male }_{i}+\beta_{4} \cdot \text { Year } \mathrm{PhD}_{i}+\beta_{5} \cdot \text { Top Author }}_{+\gamma \cdot \text { Affiliation }+\lambda \cdot \mathrm{PhD}_{i}+\delta \cdot \text { Department }_{2019 i}+\mu \cdot \text { Region }_{i p}}
\end{array}\right)+\varepsilon_{i p}
\end{aligned}
$$

The standard errors $\left(\varepsilon_{i p}\right)$ are clustered at the individual level and are robust to heteroscedasticity. Figure 2 shows the average marginal effects for each type of journal. $^{20}$

Consistent with the integration of economic history into economics, the coefficient for Year Publication is significant and positive for EFJs. Interestingly, the coefficient is negative for EBHJs, suggesting that economic historians' greater focus to publish in EFJs might have meant choosing not to publish in field journals. ${ }^{21}$ The coefficients imply that, ceteris paribus, the probability of economic historians

\footnotetext{
17 Because many authors penned more than one article, the number of authors for the variables in Table 1 exceeds the number of individuals in the sample (919).

18 The data show that when looking at the percentage instead of the share of authors of the papers, men represent 76.5 percent of the sample.

${ }^{19}$ In our dataset, only 9 percent of individuals with an economic history degree studied in North America. In the USA, economic history programs have mostly disappeared, and there has also been a significant reduction in economic history requirements for doctoral students in economics (Diebolt and Haupert 2018; Margo 2021: 13-4; Temin 2013. Of those individuals working in Economic History departments, 90 percent are in Europe and less than 8 percent are in North America.

20 The tables with the coefficients are shown in online Appendix B.

21 Our results do not substantially change if, instead of using EBHJ as one of our dependent variables, we use an indicator variable that excludes business history journals and equals 1 for journals that have at least one ASJC for Economics or Finance and another one for History but without a code for any other discipline. (Results available upon request.).
} 
Table 1 Summary statistics for articles and authors

\begin{tabular}{|c|c|c|c|c|c|}
\hline Variables & $N$ & Mean & Std. Deviation & Min & $\operatorname{Max}$ \\
\hline \multicolumn{6}{|l|}{ Panel A: published article variables } \\
\hline \multicolumn{6}{|l|}{ Journal type } \\
\hline Economics/finance & 12,364 & 0.22 & 0.41 & 0 & 1 \\
\hline Economics/business History & 12,364 & 0.28 & 0.45 & 0 & 1 \\
\hline History & 12,364 & 0.03 & 0.18 & 0 & 1 \\
\hline \multicolumn{6}{|l|}{ Decade of publication } \\
\hline Year (all) & 12,364 & $2,006.86$ & 10.00 & 1980 & 2019 \\
\hline $1980 \mathrm{~s}$ & 1,001 & $1,984.97$ & 2.80 & 1980 & 1989 \\
\hline $1990 \mathrm{~s}$ & 1,845 & 1995.04 & 2.83 & 1990 & 1999 \\
\hline $2000 \mathrm{~s}$ & 3,269 & 2005.18 & 2.86 & 2000 & 2009 \\
\hline $2010 \mathrm{~s}$ & 6,249 & 2014.75 & 2.85 & 2010 & 2019 \\
\hline Number of Authors per Article & & 2.00 & 0.99 & 1 & 5 \\
\hline \multicolumn{6}{|l|}{ Panel B: individual variables } \\
\hline \multicolumn{6}{|l|}{ Author Affiliation } \\
\hline Economic History Association & 12,364 & 0.61 & 0.49 & 0 & 1 \\
\hline Cliometric Society & 12,364 & 0.55 & 0.50 & 0 & 1 \\
\hline $\begin{array}{l}\text { Economic History Society (2018 and } \\
2019 \text { annual meetings) }\end{array}$ & 12,364 & 0.18 & 0.38 & 0 & 1 \\
\hline $\begin{array}{l}\text { European Historical Economics Soci- } \\
\text { ety ( } 2017 \text { annual meeting) }\end{array}$ & 12,364 & 0.21 & 0.41 & 0 & 1 \\
\hline Male & 12,364 & 0.85 & 0.36 & 0 & 1 \\
\hline \multicolumn{6}{|l|}{ Doctoral Degree } \\
\hline Economics or Finance & 12,265 & 0.71 & 0.45 & 0 & 1 \\
\hline History & 12,265 & 0.10 & 0.30 & 0 & 1 \\
\hline Economic History & 12,265 & 0.15 & 0.36 & 0 & 1 \\
\hline Year Ph.D & 12,364 & 1991 & 14.37 & 1951 & 2019 \\
\hline \multicolumn{6}{|l|}{ Department Location (in 2019) } \\
\hline Business/Accounting/Management & 12,235 & 0.03 & 0.16 & 0 & 1 \\
\hline Economics/Finance & 12,235 & 0.67 & 0.47 & 0 & 1 \\
\hline History & 12,235 & 0.08 & 0.27 & 0 & 1 \\
\hline Economic History & 12,235 & 0.12 & 0.33 & 0 & 1 \\
\hline \multicolumn{6}{|l|}{ Continent Location } \\
\hline Africa & 12,337 & 0.00 & 0.05 & 0 & 1 \\
\hline Asia & 12,337 & 0.03 & 0.17 & 0 & 1 \\
\hline Europe & 12,337 & 0.43 & 0.50 & 0 & 1 \\
\hline North America & 12,337 & 0.49 & 0.50 & 0 & 1 \\
\hline Oceania & 12,337 & 0.04 & 0.18 & 0 & 1 \\
\hline South America & 12,337 & 0.01 & 0.08 & 0 & 1 \\
\hline Top Authors & 12,364 & 0.44 & .050 & 0 & 1 \\
\hline
\end{tabular}



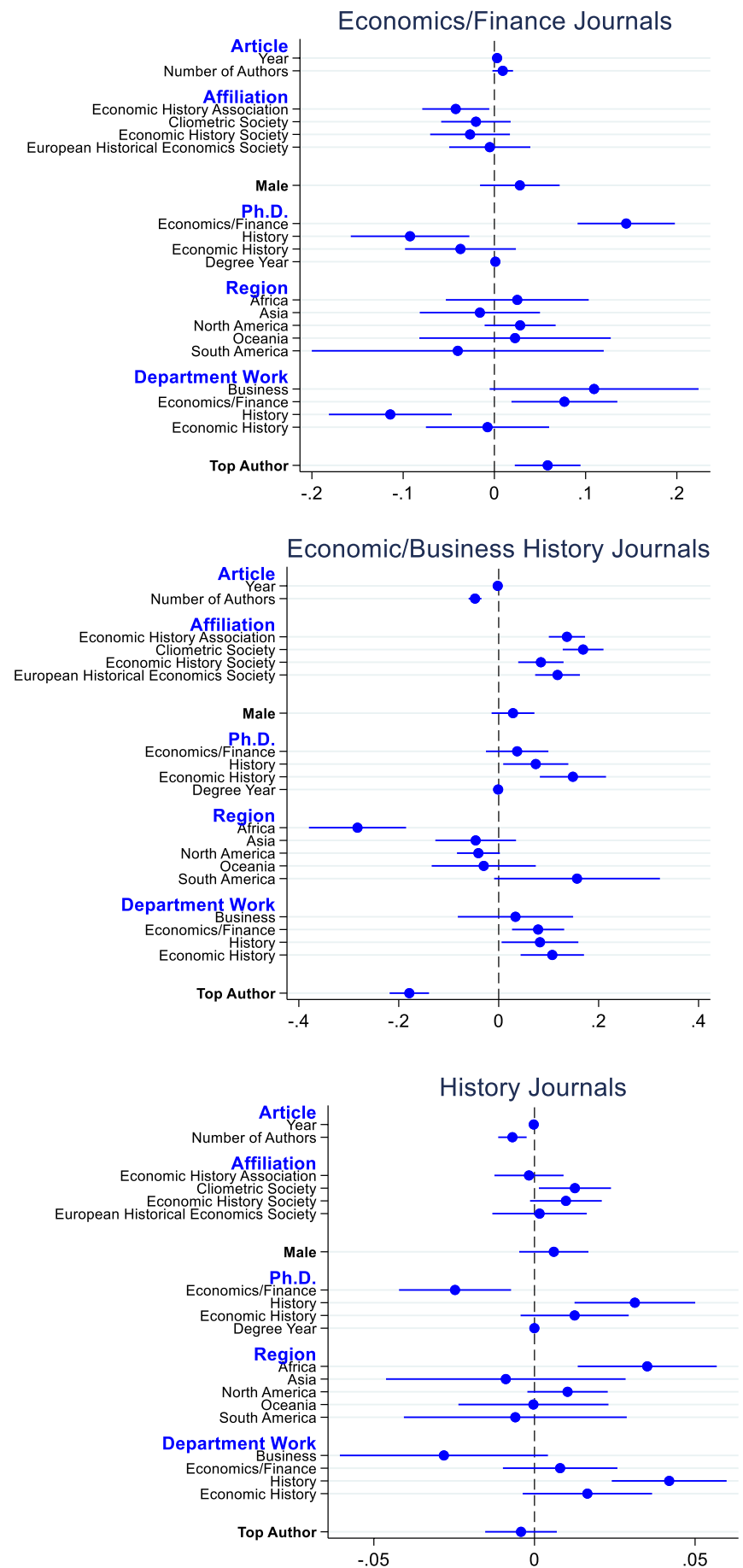

Fig. 2 Average marginal effects for the probability of publishing in EFJs, EBHJs, and HJs (95\% confidence intervals) 
publishing in EFJs between 1980 and 2019 increased by 12 percentage points, but decreased by almost 8 points for publishing in EBHJs.

Our results align with (Seltzer and Hamermesh 2018) that there is less coauthorship in economic history than economics (2018). For each additional coauthor, the probability of the article being published in an EBHJ decreases by 4.7 points.

Academic backgrounds and professional departments have an expected impact on the probability of publishing in each type of journal. Scholars holding a doctoral degree in economics, economic history, or history are more likely to publish in journals from their respective disciplines. However, we also observe negative cross-disciplinary effects between economics and history. Economic historians with a Ph.D. in economics or finance are 2.5 points less likely to publish in HJs. Likewise, those with a Ph.D. in history are, ceteris paribus, 9.2 points less likely to publish in EFJs. These results probably reflect the substantial methodological differences between economics (or finance) and history.

Similar conclusions hold for departments: Scholars working in Economics, Economic History, or History departments are significantly more likely to publish in journals specialized in those respective disciplines. There is, though, one significant nuance to the coefficients for individuals' departments: people teaching in Economics/Finance, Economic History, or History departments show a similarly high propensity to publish in EBHJs than those who work in other departments. EBHJs publish authors from the most diverse professional and educational backgrounds for the three disciplines we consider, and they are the only outlets in our study in which people with a Ph.D. in a field different than the journal have a higher propensity to publish in them. ${ }^{22}$

Membership in economic history associations or attendance at economic history meetings is a (generally) expected positive sign for publication in EBHJs. Attendees of Economic History Society annual meetings are significantly more likely to publish in HJs, which is not surprising given the mission and scope of the society ${ }^{23}$. Finally, and perhaps more surprising, Economic History Association members are significantly less likely to publish in EFJs than in the other two journal types.

The most prolific authors in the dataset also drive the integration of economic history into economics. This "bibliometric elite" in economic history is 5.8 points

\footnotetext{
22 Regression coefficients in Appendix B suggest that the influence in publications of the Ph.D. discipline matters more than the professional context. Imagine two individuals: Clio (C) and Echo (E). C received an economic history $\mathrm{Ph} . \mathrm{D}$. and works at an economics department. E trained in economics and works in an economic history unit. According to coefficients in table B.1, C's employment in economics increases the chances of publishing in EFJ by 7.7 points (the coefficient for an economic history Ph.D. in B.1 is not significant). $\mathrm{C}$ is also, ceteris paribus, 22.8 points $(14.9+7.9$; see table B.2) more likely to publish in EHBJ. On the other hand, E's education makes her 14.5 points more likely to publish in EFJ, while her economic history job increases her chances of publishing in EBHJ by 10.7 points. In sum, our results predict that the chances of publishing in journals from the Ph.D. discipline increase more for individuals with different disciplines for their education and employment.

23 The organization's website states: "The Economic History Society exists to support research and teaching in economic and social history, broadly defined" (see https://ehs.org.uk/about/; accessed on February 10,2021$)$.
} 
more likely to publish in EFJs, and these same individuals are 17.9 points less likely to publish in EBHJs and neither more nor less inclined to publish in $\mathrm{HJs}^{24}$.

With few exceptions, the dummies for the work region do not show significant differences in the propensity to publish in different outlets. (Europe is the omitted category in the regression.) Then, what explains the difference between Europebased and North America-based economic historians on where they chose to publish (see Fig. 1)?

One salient difference is their academic training (which correlates with types of publication; see Fig. 2). ${ }^{25}$ The number of economic historians with a Ph.D. in economics is much larger in North America than in Europe, and the gap has widened over time. (The percentage of economics-trained economic historians in North America with at least one publication in a decade went from 77 percent in the 1980s to 83 percent in the 2010s.) In Europe, the share of authors with an economics Ph.D. during this same 4o-year period decreased from 50 percent to less than 45 percent. The gap reflects an institutional difference between the two continents: most European scholars in the economics field were awarded a degree in economic history, a diploma that has almost completely vanished in the USA. Nearly one-fourth (24 percent) of European scholars publishing in the 1980s had been awarded a Ph.D. in economic history, which increased to 29 percent in the 2010s. In North America, the percentage of scholars with a Ph.D. in economic history decreased from 8 percent in the 1980s to less than 4 percent in the 2010s. The widening gap between the two regions in the percentage of individuals with an economic history degree also explains the higher propensity of European scholars to publish in EBHJs, despite the downward temporal trend shared with North Americans.

Finally, even if publication in HJs by economic historians remains relatively low for both continents, Fig. 1 suggests that in the 2010s, North American scholars were publishing less in those outlets than were Europeans (something that did not happen in the 1980s and 1990s). The percentage of European scholars holding a Ph.D. in history or working in a History department in the 2010s (21 percent and 16.5 percent, respectively) can help explain this difference. In North America, the number of economic historians with degrees in history or teaching in History departments has continuously declined over the last 40 years. Of those who worked in North America and published one or more articles in the 2010s, only 8.5 percent had a Ph.D. in history and 7.6 percent worked in a History department. In Europe, the percentages were 21 and 17, respectively. The differences in the relative importance of scholars in North America and Europe with training or professional affiliation in history also contribute to the relative greater propensity of North America-based economic historians to publish in EFJs.

In sum, our results have shown that economic historians increasingly published in EFJs between 1980 and 2019. This trend is more robust in North America, primarily

\footnotetext{
${ }^{24}$ Results are robust to different specifications (linear probability model or probit) and different assumptions about the time that it takes to publish an article that was started when the scholar was based in the other region (four to five years instead of three). See Online Appendix C.

${ }^{25}$ Online Appendix D provides complete summary statistics for individuals in the dataset by region and decade.
} 
due to the overwhelming share of economic historians with training in economicswhereas in Europe, a significant share of economic history scholars have doctorates in economic history and divide their publishing more evenly between EFJs and EBHJs.

\section{Network visualizations}

Figures 3, 4, 5, 6 visualize the trends mentioned above by comparing the sources cited by economic historians who completed economics $\mathrm{PhD}$ degrees in North America with those awarded economic history $\mathrm{PhD}$ degrees in Europe. ${ }^{26}$ The following figures use the regional criterion (North America and Europe) and authors' academic training (i.e., economic history for Europeans and economics for North Americans). To delve further into the differences between the two groups, we used the EconHist database. In Fig. 3, the network map shows co-citation patterns of journals cited at least 150 times. Node size reflects the number of citations, lines correspond to the existence of a citation in either direction, and the distance between nodes reflects the tendency of journals to be cited together.

Figure 3 shows that the sources used by European economic historians with 150 citations or more are grouped into three clusters, although mostly in the larger EBHJ (blue) cluster and EFJ (red) cluster. Although the Journal of Economic History is a leading EBHJ, it forms a cluster with publications from other disciplines that specialize in interdisciplinary research (in the green cluster).

The journals cited by European-based scholars with a Ph.D. in economics are evenly distributed between EFJs and EBHJs. Among the 20 journals that received the most citations, seven are EFJs and six are EBHJs; there was one HJ (Journal of African History) and other interdisciplinary or history-oriented journals (e.g., Past \& Present, World Development, Population Studies). ${ }^{27}$

When looking at the publications that received at least 200 citations by economics-trained North American economic historians (Fig. 4), we find a much denser network with more outlets, probably because there are many more individuals in this cluster of authors than in the corresponding network for European scholars trained in economic history. We created Fig. 4 using VOSviewer (V. 1.6.17). The network map shows co-citation patterns of the journals cited at least 200 times. Node size reflects the number of citations, lines correspond to the existence of a citation in either direction, and the distance between nodes reflects the tendency of journals to be cited together. The most striking difference between Figs. 3 and 4 is the centrality of the core or top economic journals among North American authors. The most prominent journals in the North American network are the American Economic Review and the Quarterly Journal of Economics (red cluster), and statistics and finance journals in the green cluster. The Review of Economics and Statistics plays a central role in the green cluster. Finally, the yellow cluster, around the Economic

\footnotetext{
${ }^{26}$ We used VOSviewer. For details, see Fernández-de-Pinedo and Muñoz (2019).

${ }^{27}$ Online Appendix E shows the tables with absolute frequencies of the journals and authors in Figs. 3, $4,5,6$.
} 


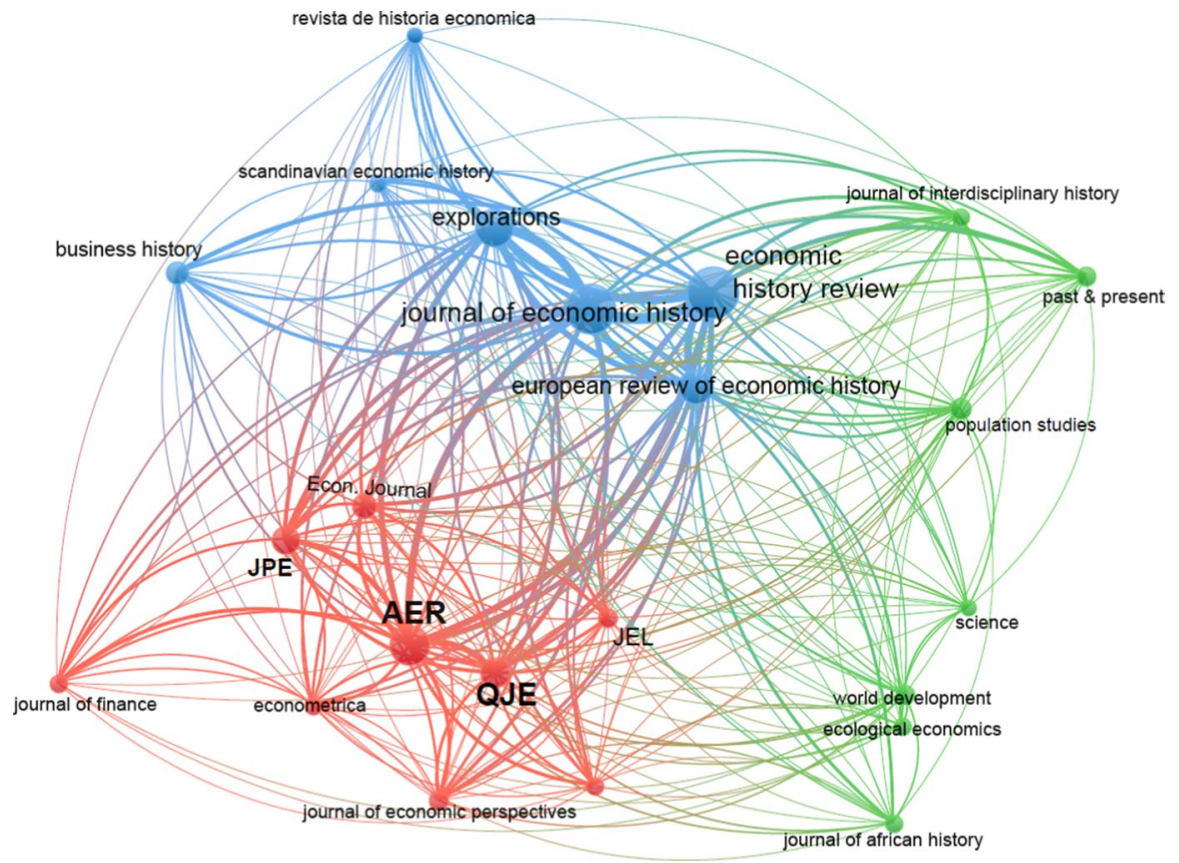

Fig. 3 Journals cited in articles coauthored by at least one individual awarded a Ph.D. in economic history from a European university

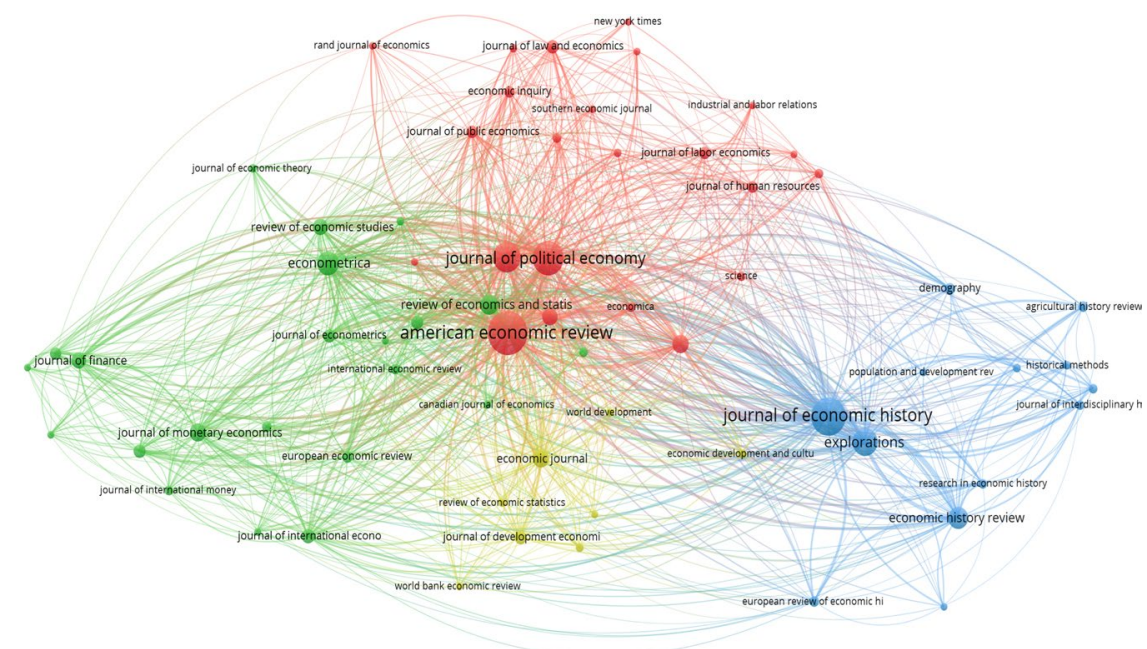

Fig. 4 Journals cited in articles coauthored by at least one individual awarded a Ph.D. in economics from a North American university 


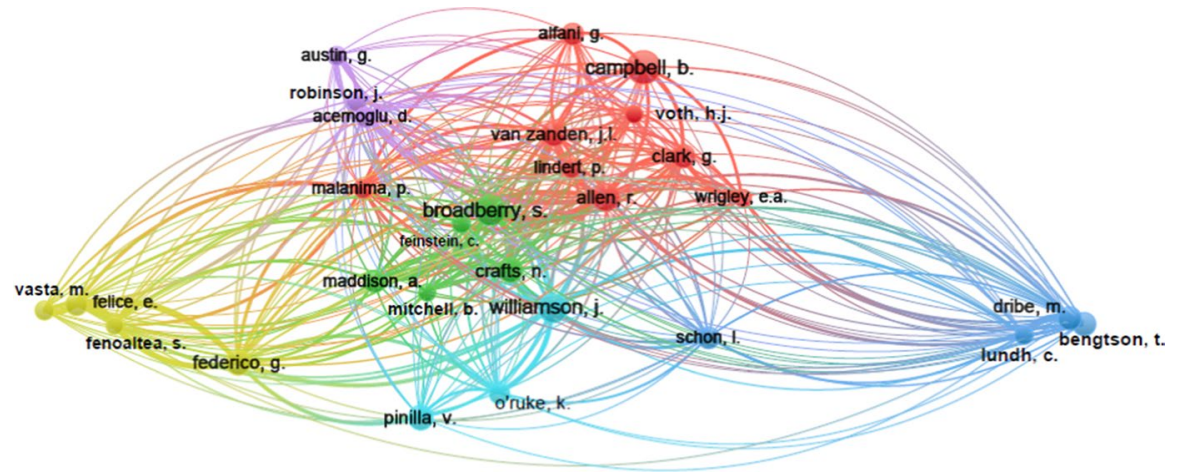

Fig. 5 Authors cited in articles coauthored by at least one individual awarded a Ph.D. in economic history from a European university

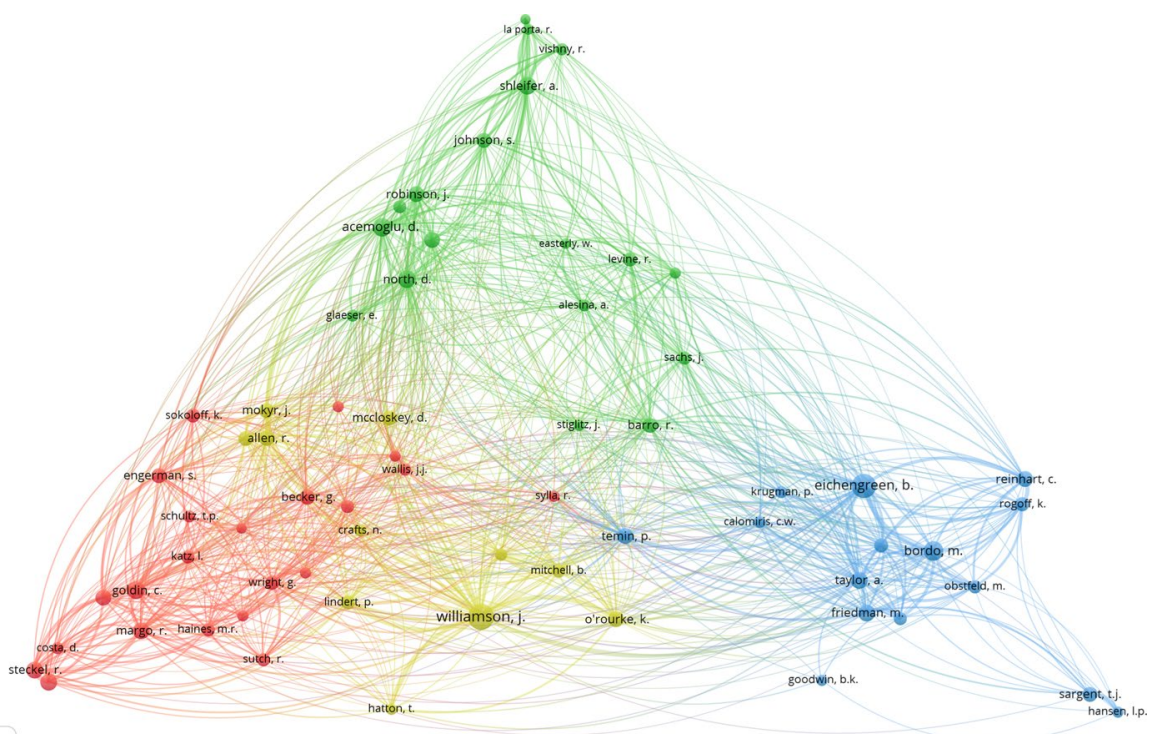

Fig. 6 Authors cited in articles coauthored by at least one individual awarded a Ph.D. in economics from a North American university

Journal, gathers journals with lower frequencies of citations. The economic history journals form a sort of 'satellite' blue cluster around three journals: Journal of Economic History, Explorations in Economic History, and Economic History Review.

The top outlets by citation among North American scholars with a Ph.D. in economics confirm the centrality of that discipline. A little more than half (11) of the top 20 journals are EFJs, while only three are EBHJs. There is not a single HJ. The six journals in the top 20 by citation that do not squarely fit into any category still have an evident economic or financial bent (Review of Economics and Statistics; 
Journal of Finance; Journal of Money, Credit, and Banking). The citations of journals reinforce the conclusion that the work of North American economic historians trained in economics (that is, the majority of the scholars in the field in that region) are more integrated into the economics discipline.

Figures 5 and 6 reflect the authors most cited by economic historians based in Europe or North America (respectively), and we can see that Fig. 5 is less dense than Fig. 6. In the European network, there are some central authors such as Stephen Broadberry, Jan Luiten van Zanden, and Jeffrey G. Williamson, who are the seeds of three distinct clusters (red, blue, and green). A case that deserves special attention is the purple cluster in Fig. 5 around Daron Acemoglu and James A. Robinson. In contrast, in the North American case (Fig. 6), there are no central authors in the network but four well-differentiated (although related) clusters around Williamson, Barry Eichengreen, Acemoglu, and Robert Margo. As with the others, these figures were created using VOSviewer (V. 1.6.17). The network map shows co-citation patterns of the economic historians cited at least 150 times. Node size reflects the number of citations, lines correspond to the existence of a citation in either direction, and the distance between nodes reflects the scholars' tendency to be cited together.

Among the 38 authors that compose the European network in Fig. 5, there are 33 (87 percent) economic historians. Only three economists-Daron Acemoglu, Angus Maddison, and Thomas Piketty (8 percent)—and two scholars from other disciplines-James Robinson and E. A. Wrigley-appear. The majority of authors cited by North Americans are still economic historians (64 percent), but the share of economists increases to more than a third (34 percent).

\section{Concluding remarks}

Writing about the relationship between economic history and economics, Diebolt and Haupert (2018: 4) asked, 'Where are we now?' This article complements and expands the growing literature on recent trends in economic history that address this question. Much in this literature references only a handful of top journals or the scholars who publish in journals from a given field. However, our starting point includes all the publications since 1980 and those scholars who self-identify as economic historians, given their affiliation to leading economic history societies or participation in economic history meetings.

Our first step was using the EconHist database, which includes scholars' publications (i.e., journal articles) and their biographical information (gender, education, place, and region of work). The dataset allows for better identification of the characteristics of practitioners in economic history. The database can be used to address Baten and Muschallik's (2012: 94) claim that 'despite this rapid globalization, however, surprisingly little is known about the scholars who represent economic history'.

EconHist is large and sufficiently representative to capture the main trends in economic history and the factors that explain them, especially for North America and Europe. This article used two empirical strategies: a probit regression to estimate the correlates for the probabilities of publishing in EFJs, EBHJs, or HJs; and 
network visualizations for the journals and authors cited by two relevant groups in the dataset (North American-based economic history scholars trained in economics and Europe-based economic history scholars trained in economic history).

Our empirical results confirm the growing integration of economic history into economics. After analyzing the outlets in which economic historians publish, we find that-between 1980 and 2019 - the probability of an economic historian's article appearing in an EFJ increased by 12 percentage points. This result aligns with what Margo found for a smaller set of North American economic historians (2018).

Margo also recognized that 'it certainly is of interest to examine whether professional behavior of scholars in economic history departments differs from that in economics or history departments' (2018: 382 n6). Our work confirms that comparing US and European economic and economic history scholars is essential to explain the regional differences in the integration of economic history into economics. Indeed, European economic historians publish less often in EFJs than do their North American counterparts, because many European scholars are trained in economic history programs. In contrast, North American economic historians are overwhelmingly trained in economics, making them more likely to publish in journals from that discipline. Our results confirm and generalize Cioni, Federico, and Vasta's results for top EFJs and EBHJs: the developments that have favored the integration of economic history into economics (e.g., the cliometric revolution, or what member terms 'the Second Revolution') are primarily North American movements (Cioni et al. 2021: 24, 28).

Given the very different behavioral outcomes for publications for Europeans and North Americans, it is reasonable to ask why economic historians are trained so differently in both regions. Is it due to the institutional differences that led to the disappearance of economic history as an independent discipline in the USA? Or are there other factors at play, like, for example, a lack of integration of the North American and European job market that facilitates the coexistence of two different methods for the practice of economic history? Does researchers' mobility have any impact on their differential careers? ${ }^{28}$ What will be the consequences of the institutional differences between Europe and North America regarding economic history as a relatively independent discipline? Are European Economic History departments doomed to eventually fade away, as happened in North America? If 'the future of economic history must be interdisciplinary' (Lamoreaux 2015), does that mean the integration of the discipline into economics is a threat to its existence? Does the rise of quantitative editors at EBHJs (Wehrheim 2018) crowd out some types of economic historians from publishing in those journals, thus affecting EBHJs' multidisciplinarity? Might economic history, as Abramitzky (2015) suggested, become more of a supplier of economic data than of history $?^{29}$ All these are important questions that

\footnotetext{
28 On the impact of mobility on researches CVs see Cañibano et al. (2020).

29 Abramitzky (2015: 1248) suggests that '[w]ith the increase ease of data collection and digitization, general economists will increasingly use the past as a natural experiment to learn about economics. Economic history has a lot to gain and not much to lose from staying integrated with economics, even if economists are not as interested in the past for its own sake as we are'.
} 
deserve further research to understand not only the recent evolution of economic history but also its future.

Supplementary Information The online version contains supplementary material available at https://doi. org/10.1007/s11698-022-00245-w.

Funding Open Access funding provided thanks to the CRUE-CSIC agreement with Springer Nature.

Open Access This article is licensed under a Creative Commons Attribution 4.0 International License, which permits use, sharing, adaptation, distribution and reproduction in any medium or format, as long as you give appropriate credit to the original author(s) and the source, provide a link to the Creative Commons licence, and indicate if changes were made. The images or other third party material in this article are included in the article's Creative Commons licence, unless indicated otherwise in a credit line to the material. If material is not included in the article's Creative Commons licence and your intended use is not permitted by statutory regulation or exceeds the permitted use, you will need to obtain permission directly from the copyright holder. To view a copy of this licence, visit http://creativecommons.org/licen ses/by/4.0/.

\section{References}

Abramitzky R (2015) Economics and the modern economic historian. J Econ Hist 75(4):1240-1251. https:// doi.org/10.1017/S0022050715001667

Angrist J, Azoulay P, Ellison G, Hill R, Lu SF (2017) Economic research evolves: fields and styles. Am Econ Rev 107(5):293-297. https://doi.org/10.1257/aer.p20171117

Baten J, Muschallik J (2012) The global status of economic history. Econ Hist Dev Reg 27(1):93-113. https://doi.org/10.1080/20780389.2012.682390

Bisin A, Federico G (2021a) Merger or acquisition? An introduction to the handbook of historical economics. In: Bisin A, Federico G (eds) The handbook of historical economics. Academic Press

Bisin A, Federico G (eds) (2021b) The handbook of historical economics. Academic Press, London

Boldizzoni F (2011) The poverty of Clio. Resurrecting economic history. Princeton University Press, Princeton $\mathrm{NJ}$

Cañibano C, D'Este P, Otamendi FJ, Woolley R (2020) Scientific careers and the mobility of European researchers: an analysis of international mobility by career stage. High Educ 80(6):1175-1193. https:// doi.org/10.1007/s10734-020-00536-Z

Cioni M, Federico G, Vasta M (2018) Ninety years of publications in economic history: evidence from the top five field journals (1927-2017). Università di Siena Working Paper, Quaderni del dipartimento di economia politica e statistica, 791

Cioni M, Federico G, Vasta M (2020a) The long-term evolution of economic history: evidence from the top five field journals (1927-2017). Cliometrica 14(1):1-39. https://doi.org/10.1007/s11698-019-00186-X

Cioni M, Federico G, Vasta M. (2020b) Three tribes: the uneasy relations between economics and economic history. Università di Siena Working Paper, Quaderni del dipartimento di economia politica e statistica 842

Cioni M, Federico G, Vasta M (2021) The two revolutions in economic history. In: Bisin A, Federico G (eds) The handbook of historical economics. Academic Press, pp 17-40

Collins WJ (2015) Looking forward: positive and normative views of economic history's future. J Econ Hist 75(4):1228-1233. https://doi.org/10.1017/S0022050715001643

Collins WJ (2018) Publishing economic history. In: Blum M, Colvin C (eds) An economist's guide to economic history. Palgrave Macmillan, Switzerland, pp 347-353

Di Vaio G, Weisdorf JL (2010) Ranking economic history journals: a citation-based impact-adjusted analysis. Cliometrica 4(1):1-17

Diebolt C, Demeulemeester JL (2007) How much could economics gain from history: the contribution of cliometrics. Cliometrica, 1:7-17. $\square$

Diebolt C, Haupert M (2016) CLIO'S contributions to economics and history. Revue D'economie Polit 126(5):971-989. https://doi.org/10.3917/redp.265.0971 
Diebolt C, Haupert M (2018) We are Ninjas: how economic history has infiltrated economics. Working Paper 04-18. Association Française de Cliométrie (AFC). https://econpapers.repec.org/paper/afcwp aper/04-18.htm

Diebolt C, Haupert M (2019) The vital tools: how economic history complements and completes the training of an economist. Presented at the American Economic Association meetings, Atlanta, GA, USA, 21 pages. https://www.aeaweb.org/conference/2019/preliminary/paper/k4KfDYh5

Diebolt C, Haupert M (2020) How cliometrics has infiltrated economics - and helped to improve the discipline. Ann of Fondazione Luigi Einaudi an Interdis J Econ Hist Polit Sci 54(1):219-230. https://doi.org/ $10.26331 / 1107$

Diebolt C, Haupert M (2021) Cliometrics: past, present, and future. Working Papers of BETA-13. https:// beta.u-strasbg.fr/WP/2021/2021-13.pdf $\square$

Ellison G (2002) The slowdown of the economics publishing process. J Polit Econ 110:947-993. https://doi. org/10.1086/341868

Eloranta J, Ojala J, Valtonen H (2010) Quantitative methods in business history: An impossible equation? Manag Organ Hist 5(1):79-107. https://doi.org/10.1177/1744935909353837

Fernández-de-Pinedo N, Muñoz FF (2019) Visualising defence and war in economic history journals (1989_ 2018). Scand Econ Hist Rev 67(3):283-311. https://doi.org/10.1080/03585522.2019.1615982

Fourie J (2019) Who writes African economic history? Econ Hist Dev Reg 34(2):111-131. https://doi.org/ 10.1080/20780389.2019.1639500

Fourie J, Gardner L (2014) The internationalization of economic history: a puzzle. Econ Hist Dev Reg 29(1):1-14. https://doi.org/10.1080/20780389.2014.922842

Galofré-Vilà G (2020) The past's long shadow: a systematic review and network analysis of economic history. In: Hanes C, Wolcott S (eds) Research in economic history. Emerald Publishing Limited

Greasley D, Oxley L (2010) Clio and the economist: making historian count. J Econ Surv 24(5):755-774. https://doi.org/10.1111/j.1467-6419.2010.00649.x

Hamermesh DS (2018) Citations in economics: measurement, uses, and impacts. J Econ Lit 56:115-156. https://doi.org/10.1257/jel.20161326

Haupert M (2017) The impact of cliometrics on economics and history. Revue D'économie Polit 127(6):1059-1081

Jones G, van Leeuwen MHD, Broadberry S (2012) The future of economic, business, and social history. Scand Econ Hist Rev 60(3):225-253. https://doi.org/10.1080/03585522.2012.727766

La Parra-Pérez A, Muñoz FF, Fernandez-de-Pinedo N (2022) EconHist: a relational database for analyzing the evolution of economic history (1980-2019). Hist Methods A J Quant Interdis Hist (forthcoming). https://doi.org/10.1080/01615440.2021.20143

Lamoreaux N (2015) The future of economic history must be interdisciplinary. J Econ Hist 75(4):1251-1257. https://doi.org/10.1017/S0022050715001679

Lyons JS, Cain LP, Williamson SH (eds) (2007) Reflections on the cliometrics revolution: conversations with economic historians. Routledge, London. https://doi.org/10.4324/9780203799635

Margo RA (2011) The economic history of the american economic review: a century's explosion of economics research. Am Econ Rev 101 (1): 9-35.

Margo RA (2018) The integration of economic history into economics. Cliometrica 12(3):377-406. https:// doi.org/10.1007/s11698-018-0170-8

Margo RA (2021) The economic History of economic History: the evolution of a field in economics. In: Bisin A, Federico G (eds) The handbook of historical economics. Academic Press, pp 3-16

McCloskey DN (1976) Does the past have useful economics? J Econ Lit 14(2):434-461

Mihaljevic J (2019) Economic history in the journal of contemporary history (1969-2018). Casopis Za Suvremenu Povijest 51(3):741-784

Mitch D (2011) Economic history in departments of economics: the case of the University of Chicago, 1892 to the present. Soc Sci Hist 35(2):237-271. https://doi.org/10.1017/S0145553200011512

Mitchener KJ (2015) The 4D future of economic history: digitally-driven data design. J Econ Hist 75(4):1234-1239. https://doi.org/10.1017/S0022050715001655

Ojala J, Eloranta J, Ojala A, Valtonen H (2017) Let the best story win - evaluation of the most cited business history articles. Manag Organ Hist 12(4):305-333. https://doi.org/10.1080/17449359.2017.1394200

Poelmans E, Rousseau S (2016) Quantifying the heterogeneity of publication cultures in economic, business, and financial history. Essays Econ Bus Hist 34:95-135

Reckendrees A (2017) Economic history in times of transition. Scand Econ Hist Rev 65(1):1-5. https://doi. org/10.1080/03585522.2017.1294378 
Romer CD (1994) The end of economic history? J Econ Educ 25(1):49-66. https://doi.org/10.1080/00220 485.1994.10844814

Seltzer AJ (2018) Publication trends and future challenges for the australian economic history review: a bibliometric analysis. Aust Econ Hist Rev 58(2):112-133. https://doi.org/10.1111/aehr.12143

Seltzer AJ, Hamermesh DS (2018) Coauthorship in economic history and economics: Are we any different? Explor Econ Hist 69:102-109. https://doi.org/10.1016/j.eeh.2018.04.001

Stigler GJ, Stigler SM, Friedland C (1995) The journals of economics. J Polit Econ 103(2):331-359

Temin P (2013) The rise and fall of economic history at MIT. Working Paper. Cambridge, MA. https:// dspace.mit.edu/handle/1721.1/79063

Waldenström D (2005) Increased international integration is a prerequisite for more and better research in economic history. Scand Econ Hist Rev 53:85-92. https://doi.org/10.1080/03585522.2005.10414261

Wehrheim L (2019) Economic history goes digital: topic modeling the journal of economic history. Cliometrica 13(1):83-125. https://doi.org/10.1007/s11698-018-0171-7

Whaples R (1991) A quantitative history of the journal of economic history and the cliometric revolution. J Econ Hist 51(2):289-301. https://doi.org/10.1017/S0022050700038948

Whaples R (2002) The supply and demand of economic history: recent trends in the journal of economic history. J Econ Hist 62(02):524-532. https://doi.org/10.1017/S0022050702000591

Publisher's Note Springer Nature remains neutral with regard to jurisdictional claims in published maps and institutional affiliations. 